\title{
Sports medicine education: Socrates, Science and South Africa
}

\author{
Jon Patricios ${ }^{\circ}$
}

\begin{abstract}
'Wonder is the beginning of wisdom. I cannot teach anybody anything. I can only make them think' Socrates (469-399 BC). ${ }^{1}$
\end{abstract}

Greek philosopher Socrates used cross-examination and interrogation of claims to test for potential contradictions or inconsistencies. This is called 'the dialectic (discussion-based) method' of inquiry. Although most clinicians are not aware of this, his ideas form the basis of the critical thinking and medical reasoning we employ in reflecting on our own clinical practices, in reviewing research and in reading the papers in this journal.

\section{NOT YOUR GRANDFATHER'S MEDSCHOOL: A NEW ERA IN EDUCATION}

Medical education has recently undergone substantial critical review in many parts of the world. Invaluable for me was a report by the American Medical Association ${ }^{2}$ on Medical Education Trends (https:// edhub.ama-assn.org/module/2706435). The changes being aptly described by Dr Timothy Smith of the AMA as 'Not your grandfather's med school...'3

Not only has medical education changed significantly since our grandparents' generation (eg, the very science-focused, lecture-based teaching evolved into a more clinically oriented approach) but the concept of Sport and Exercise Medicine (SEM) as a distinct specialty and a core part of the medical curriculum would not even have been entertained. To those of us in the SEM trenches this seems bizarre. The benefits of cardiorespiratory fitness (in no way a new discovery!) succinctly summarised in the infographic by Smirmaul and Arena (see page 614) in this edition seem so clear and permeate every facet of clinical medicine. Even Socrates recognised this 2500 years ago saying 'No man has the right to be an amateur in the matter of physical training. It is a shame for a man to grow old without seeing the beauty and strength of which his body is capable.'

Correspondence to Professor Jon Patricios, Faculty of Health Sciences, Wits Institute for Sport and Health (WISH), University of the Witwatersrand, Johannesburg 2000, South Africa; jpat@mweb.co.za

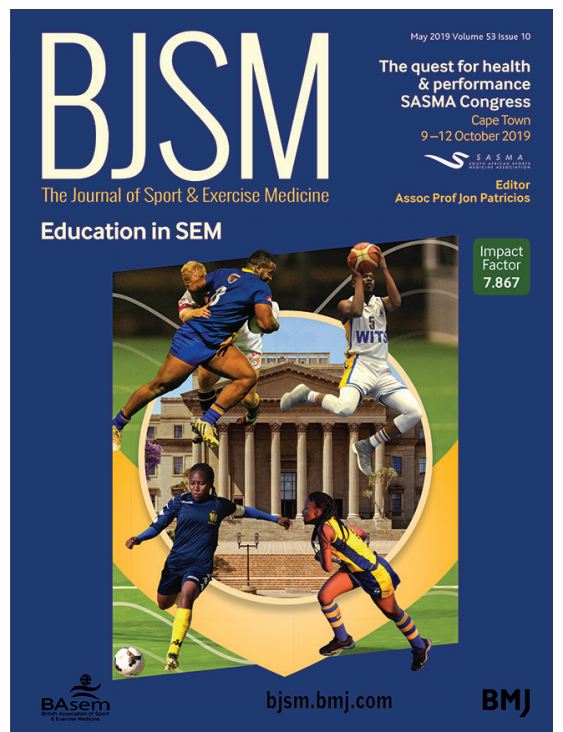

Figure 1 Celebrating Sport and Exercise Medicine education.

\section{SOUTH AFRICAN LINKS}

This South African Sports Medicine Association (SASMA)-guided edition (figure 1) of BJSM explores some novel concepts in SEM education and means in which education has been used to promote interventions in different clinical settings. We unapologetically promote some work by South African researchers and clinicians (Schwellnus, Hendricks, Holtzhausen, Dijkstra and Zondi) as well as some who have associations with South Africa (Kate Ackerman, a recent SASMA conference guest).

\section{INNOVATION ... WITHOUT IGNORING} THE SCIENCE

As peculiar as it may appear that SEM has only recently emerged to stake a claim as a field of study worthy of specialty status, its modern genesis provides a number of opportunities in formulating novel curricula. The traditional training model of lectures, tutorials and practical learning exposure based in medical schools teaching hospitals can (has!) been turned on its head by internet access, social media exposure and global networking. As a new field, SEM has the opportunity to define its own syllabus boundaries. The Australian
College ${ }^{4}$ and UK Faculty of SEM $^{5}$ have done this assiduously, devising curricula combining theory and practice, course work and research, hospital and field settings and exposure to state and private practice settings.

In this edition Barton and Merolli (see page 594) highlight the importance of digital innovation in knowledge translation and the multimedia dissemination of innovation. Gabbett and Blanch (see page 592) focus on some of the pitfalls and remind us that 'empirical evidence is the ultimate arbiter.'

Widespread broadband access has made online tuition such as those described by Mah from Melbourne (see page 607) part of mainstream education. Podcasts (BJSM leads the way http:// feeds.bmj.com/bjsm/podcasts) allow for 'tutorials in transit' as cars, buses and trains become the new lecture halls, and Massive Open Online Courses (I've recently signed up for the IOC courses http://onlinecourse.olympic.org/ course/index.php?categoryid=2) allow access to international experts such as SASMA friend@ProfJillCook, without having to increase our carbon footprint.

The UK's Ann Gates and colleagues (see page 609) outline the M4M ('Movement for Movement') initiative to drive physical activity promotion into undergraduate medical school curricula emphasising the potential for national and global dissemination. There is a risk of exercise 'science' being manipulated as it gains traction in the public domain, especially where there is an element of commercial gain. Diagnostic biomarkers, genetic testing for sports performance, sports supplements and ever-changing nutritional fads are the more obvious examples. We need to remain cynical gatekeepers of evidence-based practices.

\section{NOVEL METHODS}

As examples of interinstitutional and multinational collaboration, Dr Sharief Hendrick's team describe a technique for measuring the load of technical skill (rate of perceived challenge) (see page 611); long-time South African, and now Qatar, sports physician Loius Holtzhausen and colleagues discuss mitigating concussion risk by 'rising to the OCAsion' using joint decision-making (see page 590). In two separate papers, prolific South African researcher and SEM stalwart Professor Martin Schwellnus reports his teams' careful evaluation of how pre-event medical screening affected relevant clinical outcomes in two quite different settings: 
(1) Cape Town's mass participation Two Oceans Marathon, and (2) five seasons of Super Rugby (see page 620). Finally, another high flyer of South African SEM, a sports physician-leader who epitomises innovation and fearless commitment to difficult goals, is featured in BJSM's interview series-Inside Track (see page 618). Dr Phatho Zondi \#TeamPlayer is an inspiration to all of us.

\section{SASMA CONTINUES TO EDUCATE: CAPE TOWN, 9-12 OCTOBER 2019}

The biennial SASMA Congress will take place in Cape Town from 9 to 12 October 2019. Themed 'The quest for health and performance', the programme will be headlined by the stellar and trenchant American physician, Harvard professor and wheelchair racer Cheri Blauwet (@ CheriBlauwettMD). Other international speakers include recent ACSM President Professor Walt Thompson (@DrWaltThompson), Dr Robbart van Linschoten (Netherlands) and Dr Nicol van Dyk (Aspetar,@NicolvanDyk), and they will serve alongside a strong Southern African cast. As always, a vibrant social programme (powered by some of the Cape's finest cultivars) will dance its way through the meeting to the beat of an African drum!
'EDUCATION IS THE KINDLING OF A FLAME, NOT THE FILLING OF A VESSEL'

The flame sparking a new era of innovative, interactive and deinstitutionalised medical education has indeed been lit. SEM is at last being recognised by universities, specialist medical colleges and governments for the essential part it plays in disease and injury prevention and intervention. This advancing wave of exposure is inspiring, exhilarating and stimulating for those involved.

Innovation is not foreign in South African SEM. Visionary @ProfTimNoakes (not unlike Socrates, a maverick who challenges boundaries) launched the first postgraduate degree in sport and exercise science in 1981 and co-founded the Sports Science Institute of South Africa in 1994. A new era of global exposure offers greater opportunities for our current cohort of educators. Socrates encouraged Athenians to embrace 'wonder' and to 'think rather than learn.' If we are to be taken seriously as scientists and clinicians in a rapidly evolving field with a high public profile, heeding carefully the advice of Socrates to be mindful and critical thinkers will serve us well.

Contributors JP conceived the article, drafted the manuscript and, after editorial feedback, edited the manuscript before final submission.
Competing interests None declared.

Patient consent for publication Not required.

Provenance and peer review Commissioned; internally peer reviewed.

(c) Author(s) (or their employer(s)) 2019. No commercial re-use. See rights and permissions. Published by BMJ.

\section{Check for updates}

To cite Patricios J. Br J Sports Med 2019;53:585-586.

Accepted 13 March 2019

Br J Sports Med 2019:53:585-586.

doi:10.1136/bjsports-2019-100729

\section{REFERENCES}

1 Paul R. Critical thinking: how to prepare students for a rapidly changing world. http://www.1000ventures.com/ business_guide/crosscuttings/questions_socratic.html (Accessed 8 Feb 2019).

2 American Medical Association. Medical Education: Healthcare trends 2016-2017 edition. https://edhub. ama-assn.org/module/2706435 (Accessed 8 Feb 2019).

3 Smith TM. Not you grandfather's med school: Changes trending in med ed. https://www.ama-assn.org/ education/accelerating-change-medical-education/ not-your-grandfathers-med-school-changes-trending (Accessed 16 Feb 2019).

4 Australasian College of Sports and Exercise Physicians. Training Program. https://www.acsep.org. au/page/about/education-and-training (Accessed 16 Feb 2019)

5 Faculty of Sports and Exercise Medicine UK. Training Pathways. https://www.fsem.ac.uk/careers-training/ training-pathways/ (Accessed 16 Feb 2019). 